\title{
Plato's Apology of Socrates and Sapientia Salomonis on atheism
}

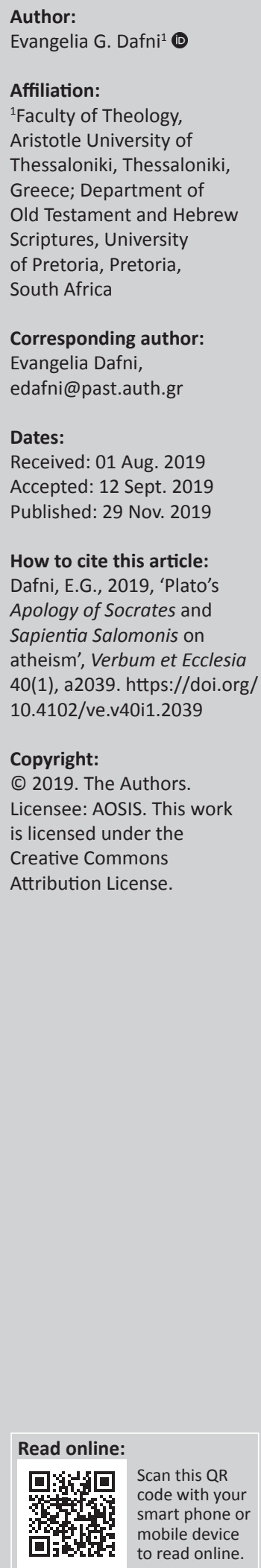

The article examines the perception of atheism in Plato's Apology of Socrates (4th century BC) in comparison to the book of Sapientia Salomonis (about 1st century BC or 1st century AD) from a cultural critical perspective. Special attention is paid to linguistic, ideological and theological aspects referring to the righteous and the godless in the face of God.

Intradisciplinary and/or interdisciplinary implications: The perception of atheism in Plato's Apology of Socrates in comparison to the book of Sapientia Salomonis is examined from the fields of Cultural Studies, Linguistics, Philosophy and Theology.

Keywords: Apology of Socrates; Sapientia Salomonis; Atheism; Righteous; Evildoers; Indictment; Prosecution; Death penalty; Final judgement; Eschatology.

\section{Introduction}

In 399 BC, three enemies of the wise and righteous Socrates accused him of corrupting the youth and of godlessness and demanded the death penalty for him. Almost a decade later, Plato presented the dialogue Apology of Socrates, ${ }^{1}$ one of the four platonic dialogues (Euthyphro, Phaedo and Crito) about the last days of Socrates. It describes the speeches of Socrates in self-defence against the unrighteous accusations at the trial. The anaginoskomenon or deuterocanonical book of Sapientia Salomonis ${ }^{2}$ (Wisdom of Salomo), a Jewish-Alexandrian work written originally in Greek perhaps in the 1st century BC, explains - especially in its first three chapters - what the impious (unrighteous and godless) believe of life as well as what they do against the righteous with the unlawful aim to destroy his or her moral and physical existence. This book of the Jewish Wisdom Literature is initiated with the call to the rulers of the earth to love justice (SapSal 1:1). Justice, 'a central theological term in the Old Testament for a life following God's commandment in fidelity to the community ${ }^{\prime}{ }^{3}$ is meant to be stressed, especially since Plato, as a cardinal virtue in the Greek culture and thought. ${ }^{4}$ Departing from this point of view, I will attempt to compare some linguistic and ideological patterns of the platonic dialogue Apology of Socrates and the book of Sapientia Salomonis with respect to the issue of atheism. ${ }^{5}$ The concept of atheism ${ }^{6}$ is expressed in both works with the word-field of $\dot{\alpha} \sigma \varepsilon \beta \dot{\eta} \varsigma$ and $\dot{\alpha} \sigma \varepsilon \dot{\beta} \varepsilon 1 \alpha$.

\section{Apology of Socrates}

The platonic Apology of Socrates includes three speeches - each separated by the votes of the judges - that seemingly reflect the actual course of events: (1) a plea, (2) a petition following the guilty verdict and (3) a farewell word commenting on the death sentence.7

After a few preliminary remarks, Socrates states that he will speak spontaneously as he had always spoken (Chapter 1). The main part of his plea is divided into two sections. ${ }^{8}$ In Chapters

1.See U. Von Wilamowitz-Moellendorff (1919:47-53), Natorp (1961:4-10), Ritter (1923:368-384), Friediander (1957:143-158), Gauss (1954:23-71), Von Kutschera (2002:71-85) and Fuhrmann (1989).

2.Cf. Winston (1979:11), Hübner (1999:153-188), Vögtle and Nützel (2000:918ff.), Bullard and Hatton (2004) and Engel (2011:2127ff.).

3.See Engel and Hiecke (2005:1291).

4.See Engel and Hiecke (2005:1291).

5.See Dafni (2018).

6.Dafni $(2018: 12$, n. 6).

7.See Fuhrmann (1989:110ff.).

8.See Fuhrmann (1989:110ff.). 
$2-10$, Socrates attempts to show that he is victim of a longstanding campaign of defamation. In Chapters 11-16, Socrates advances his argumentation relating to the absurdity of the indictment. He deals first with the accusation of corrupting the youth and then with the offense against the gods of Athens ( $\dot{\alpha} \sigma \dot{\varepsilon} \beta \varepsilon 1 \alpha)$. In Chapters 16-22, Socrates presents his deeds as a mission given to him by God, a true divine vocation in life to be a philosopher, namely, to be a lover of wisdom, to destroy the common misconceptions about the value of fame and fortune and to diminish people's main concern for their own lives. This mission could not be distracted by the impending danger of death. Chapters 25-28 contain the most interesting challenge of the tribunal. Socrates believes that instead of punishment, he deserves a reward. Exile as the usual ban on an asebeia process would have prevented him from continuing his previous work as a human examiner, and such a life was not worth living for Socrates. The farewell word after the final judgement (Chapters 29-33) deals with the meaning of death, the question of whether death is an evil or a good thing, reminding the problematic of Genesis 2-3.

\section{The indictment}

Socrates was accused of being wrongdoer, who acted unlawfully, corrupted the youth and did not recognise the gods of the state, but worshipped other demonic beings (24b). ${ }^{9}$ The platonic Apology exposes the following fallacies ${ }^{10}$ in this indictment, namely, the accusers of Socrates - based on a false analogy, falsely presenting it as self-evident brought forth familiar motives that were at hand against all those who practised philosophy, namely, the celestial phenomena and the subterranean, the denial of the gods and the endeavour to make the weaker speech stronger. He did not obey the seer and fear death, and he considered himself wise without being one (28e-29a). For this faulty reasoning, one could kill or banish him or dishonour him by taking away his civil rights (30d). Meletos, however, demands death as the proper punishment. The platonic Socrates, on the other hand, points out the failure in reasoning and the invalidity of the argumentative discourse. He emphasises that the unjustifiable death is the greatest evil (30d) and that he uses the right of self-defence as an Athenian legal justification not for his own sake, but rather for the sake of Athenian judges, to protect them from killing him unjustly and thereby committing a sin against the gift God gave to the city (30d-e).

\section{Slanderers and prosecutors}

Several slanderers were at work against Socrates (18b.19a): (1) on the one hand, those who for many years from envy and abuse spread lies and made mood against Socrates (18d), as depicted in the comedy Clouds by Aristophanes and (2), on the other hand, the clique of the Athenian upper-class politician Anytos. From their midst appeared

9.Translation of the Apology and wording of our argumentation according to H.N Fowler (1966).

10.See Van Eemeren and Grootendorst (1992:208ff.). as prosecutors to transform the slander into a legal case and present it in a trial against Socrates accused of breaking the Athenian law: (1) Meletos for the poets; (2) Anytos for the craftsmen and politicians; and (3) Lykon for the orators (23e).

Socrates admits that he feared the slanderers more than the prosecutors because they remain anonymous, work in the dark and raise their charges against an absent man without a defender ever appearing (18c). In this way, he summarises the work of the anonymous God's adversary in Genesis 3, characterised as נחש without being one, who makes a false spoken statement intended to mislead the human beings, to instigate rebellion, to damage the personal relationship between God and the protoplasts and to cause death. ${ }^{11}$ The slanderers of Socrates whispered in the ear to the Athenian youth and adults that there is a Socrates who is a wise man, who explores the celestial phenomena and everything subterranean and makes the weaker speech to seem stronger' (18b). By distorting Socrates's standpoint and inputting a fictitious one, the slanderers misled people to believe that someone, who studies these things, cannot believe in the existence of gods (18c). ${ }^{12}$ Hence, the charge

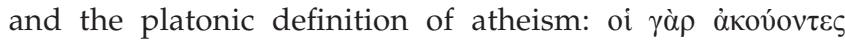

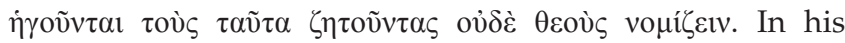
apology, Socrates attempts first to refute the accusations of the slanderers and defend himself according to God's will and obeying the Athenian law against unlawful, insidious attacks of his prosecutors (19a).

The platonic Socrates makes clear from the beginning that his prosecutors have not said the truth (17c). They made personal attacks on him by speaking in an impudent and lying manner so that even he 'could not have recognized himself under their impression' (17a). He also attacks them personally by depicting them as stubborn and people who are numerous and 'have completely stuffed the ears of the judges with their constant massive slander'. They insistently demand the conviction of Socrates for corrupting the youth and atheism (23e). Socrates exposes them as liars and explodes at their logically invalid arguments. Although he - convinced that he was right in this matter - had not prepared his speech and spontaneously tried in unschooled terms to refute their arguments, they warned the judges in advance that he used to be a dangerous orator $(17 b-c)$. Socrates ironically calls Meletos, 'right-thinking and

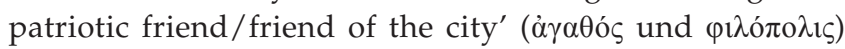
(24b). In this way, Socrates points out the inconsistency between the words and deeds of Meletos and casts serious doubts on his version of events and motives. The irresponsible attitude of Socrates is proven by the fact that Meletos acts unlawfully because:

$[H]$ jokes in a serious matter by frivolously bringing people to justice and posing as if he were the guardian of things he had never cared for all his life. (24c; 26e; 27a-b)

\section{See Dafni (2015a)}

12.The Decalogue, however, speaks of deification of celestial and subterranean phenomena that people of God must avoid (Ex 20:4f.; Dt 5:8f.). 


\section{Ideal judge and ideal orator}

According to Socrates, the ideal judge is one who makes legal decisions in a court, who has the authority to decide impartially and without bias (35c):

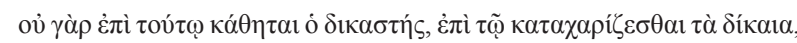

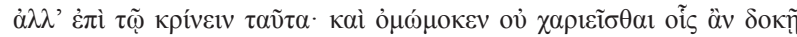

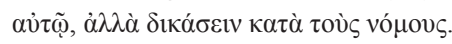

[For the judge is not here to grant favours in matters of justice, but to give judgement; and his oath binds him not to do favours according to his pleasure, but to judge according to the laws.]

The virtue of the judge is to know if someone is right. The virtue of the orator is to speak the truth $(17 \mathrm{~b})$ :

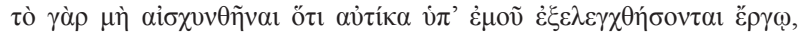

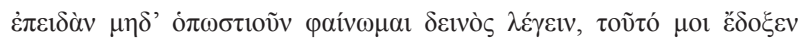

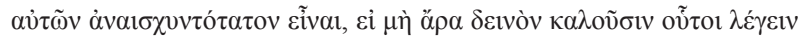

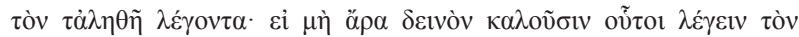

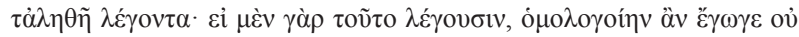

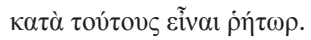

[For I thought it the most shameless part of their conduct that they are not ashamed because they will immediately be convicted by me of falsehood by the evidence of fact, when I show myself to be not in the least a clever speaker, unless indeed they call him a clever speaker who speaks the truth; for if this is what they mean, I would agree that I am an orator - not after their fashion.]

These statements go against the efforts of the orators (attorneys at the time) to win the trial and receive funds, regardless of whether their client was right or wrong.

\section{Socrates argumentative discourse}

Socrates analyses the formulations and the logical strategy of his prosecutors as carefully and accurately as possible. He examines the single arguments to ascertain if they are logically and ethically valid or invalid. Regarding corrupting the youth, he raises first the question 'who can educate and improve the young people'. From the standpoint of his prosecutors, it results that educators of the youth could be the laws, the judges, the councillors, the people of the assembly as well as the guests, all Athenians except Socrates. Furthermore, they accused him of taking money for educating people, like the sophists, a profession disregarded by Socrates. It is noteworthy that the sophists were wisdom teachers who move from city to city and persuade young people to break off the free gratuitous dealings with their fellow citizens, to join them for a fee and above all to be grateful to them. The real cause of such prejudices against Socrates and this bad reputation is a kind of wisdom beyond the human measure attributed to him by his slanderers and prosecutors. This prejudice goes back to the Delphi oracle and to Chairephron, who asked Apollo for information, whether anyone was wiser than Socrates (21a). Pythia assured him that there was definitely no one wiser than Socrates. This narrative about the oracle is a way of building a bridge between the accusation of corrupting the youth and the charge of atheism. The claim that he does not believe in God is disproved by saying that Socrates asks for the deeper meaning of the divine word, 'Socrates is the wisest of all' (21b). Socrates asks seriously about the hidden meaning of the divine words and admits that he is fully conscious that he is not wise, neither much nor little. He also confesses his belief in a God - namely Apollo - who does not lie, unlike the complex view of Apollo by Homer or the Tragedians.

Socrates describes his way of investigating the divine word, which he raised above everything else, as follows, namely, he went at first to the politicians who had the reputation of being wise men and tested whether they were wiser than he was. He realised that they simply pretended to know something, even though they knew nothing. After the politicians, he went to the poets, the tragedians and the dithyramb writers and examined them according to divine instruction. He understood at once that everything the poets produced did not come forth out of wisdom but of a special predisposition and in divine enthusiasm, like the seers and oracle singers. They say beautiful words without really knowing what they say (22c), although they think they are very wise people as well. Finally, Socrates went to the artisans who understood each other well enough to practice their own art. Everyone of them imagined that he were also incredibly wise. From this investigation, many enmities and prejudices arose against Socrates, as well as the reputation that he was a wise man. Socrates, however, expresses his conviction that God alone is truly wise and his oracle seems to mean that human wisdom is little or nothing worth; the name of Socrates was only incidentally mentioned and used as an example (23b): 'oṽ̃o

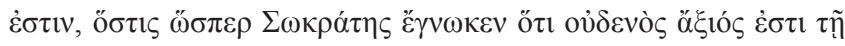

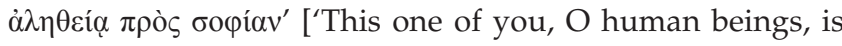
wisest, who, like Socrates, recognises that he is in truth of no account in respect to wisdom']. Therefore, Socrates perceives his vocation in life as an employment in the service of God, whenever he assumes that a native or a non-native is wise. Because of this, Socrates 'never found time for none of the notable achievements in public service or private affairs and lived in profound poverty'. Young people, mostly children of the richest Athenian families who had time, enjoyed hearing Socrates by testing people and voluntarily imitated him. Those who had been tested by them were angry with Socrates (cf. 23c-d; 33d).

The second argument of Socrates against the charge of corrupting the youth $(25 c-d)$ is that it is better to live among righteous citizens than under bad people. If someone deals with a bad person, he assumes the full risk of suffering evil. If anyone has a bad effect on the character and the behaviour of young people unwillingly, then this does not entail punishment, but requires instruction.

The third argument against the assertion that 'Socrates does not recognize the gods recognized by the Athenian state, but others, novel demonic beings and this has a pernicious influence on the young people' (26d-e): it is not possible that 
one believes that there are demonic things, but not demons $(27 \mathrm{c}-\mathrm{d})$. If one thinks that:

$[D]$ emons are gods or children of gods or hybrids of nymphs or any other beings, as it has been handed down, it is completely impossible to believe that there are children of gods, but not gods, to believe in demonic and divine things, but not to believe in demons or gods as in heroes. (27e-28a)

If Socrates was faced with the dilemma to stop philosophising and live or to practice philosophy for the Athenians and die for God, then he would definitely choose the second, even if the former choice could bring him much money, physical well-being, honour and esteem (29d-e). He was zealous for the best possible condition of the soul (30b). Therefore, he would not stop to examine younger and older, natives and foreigners and investigate whether they possess virtue and wisdom; he considered this as a greater blessing in the service of God (30a). He thought that it is not the wealth that produces moral value, but the moral value produces wealth and all other goods for each individual and for the general public (30a).

In summary, Socrates assures that he believes in God like none of his accusers and he is not a teacher like the sophists because he is not paid by anyone. Instead of receiving wages and getting rich, he decided to be poor in the service of God. $\mathrm{He}$ is convinced that he is sent by God to the city to test himself and others and lead them to the practicing of virtue, justice and truth.

\section{The prophetic function of Socrates}

Socrates states firmly that his mission is imposed on him by God through oracles, dreams and in every way in which a divine authority ever imposed anything on a person at all (33c). It should be reminded that wise and righteous men are also mentioned in the Old Testament as revelation instruments (see e.g. Joseph, Salomo and Daniel), especially in relation to the so-called natural revelation of God in the Gentiles (Job). ${ }^{13}$

Socrates, convinced that he is not speaking in a spirit of arrogance, insists that he never intentionally wronged anyone. He also asserts that (40a) a prophetic voice, a divine sign, usually, but not in this case, speaks in him. He names daemonion as the voice that makes itself very often noticeable, even in very unimportant things, when Socrates is about to do something wrong. The divine voice was always in him since his youth and advised him against everything wrong he was about to do. She stopped him from doing politics but not from defending himself at the trial (31d).

Socrates did not care about anything that concerned him, but always cared for the affairs of others by talking to the conscience, like the father or an older brother and advising everyone to strive to become a good person (31b). Worthy of mention is that he did not appear before the public but gave advice individually.

13.See Dafni (2001:295-310)

\section{Socrates's death}

Why Socrates prefers to die instead of fleeing is shown in his judgement on the death of Achilles (28c-d), who was 'much more afraid of staying alive as a coward instead of revenge on his friends'. Socrates, instead of dying at Potidaia or Amphipolis or Delion, or being out of fear of death, preferred to stay where God placed him, namely, to live as a philosopher and to test himself and the others. Socrates equates two things: (1) being afraid of death and (2) believing to be wise without becoming one (29a). He emphasises that no one knows anything specific about the conditions in the hereafter (29b), whether death is not the greatest of all benefits to man. Human beings fear him as if they knew perfectly well that he is the greatest of evils (29a). Socrates, however, knows only one thing for sure: 'It is bad and harmful to do wrong and disobey the better, a god or a man' $^{\prime}(29 b)$.

By showing the vain of his death penalty, Socrates makes his judges aware of his advanced age and his proximity to physical death (38c-d; cf. 2Macc 6:18-31 and 4Macc 5ff.). He abides his death penalty, but he thinks that, in the end, his accusers will be found guilty of baseness and injustice (39b).

The platonic Socrates brings up his eschatological expectations by raising the question, whether to die physically is something good or bad (40c). He stresses, how great is the hope that death is at the end, a good thing. Thus, he gives two definitions of death (40c-e): (1) 'a kind of non-being' and (2) 'a kind of transition and resettlement of the soul, from the place here to another place'. In the former case, death as a 'kind of sleep, in which the dormant person has no dreams, would be a wonderful gain'; 'the whole time continuum does not seem to us any longer than a single night'. In the latter case, one is liberated from the so-called judges of this world and enters into another world where there are the true judges (Minos, Rhadamanthys, Aiacos and Triptolemos), all the demigods who have proved to be just in their lives (Orpheus, Museus, Hesiod and Homer) all those of the past, who were killed by an unjust verdict (Palamedes, Ajas of the Telamonians), or countless men and women who could otherwise be named (Odysseus, Sisyphus, etc.). Socrates thinks that it would be a great privilege to talk to them and to be together with them and to test them, who would be immortal for any further time, if true, what is reported about them. In this way, the platonic Socrates expresses his belief in afterlife and immortality of the wise and righteous people (41c).

\section{Final judgement}

Socrates is confident $(41 \mathrm{c}-\mathrm{d})$ that no evil can befall a good man, either in life or after death, and 'God does not neglect him'. He is rather convinced that it would be the best for him 'to die at that time and be freed from troubles'.

In the end of his argumentative discourse, Socrates settles himself in the hands of God and concludes his apology with the following words: 
But now the time has come to go away. I go to die, and you to live; but which of us goes to the better lot, is known to none but God. (42a)

\section{Sapientia Salomonis}

The book of Sapientia Salomonis seems to begin where the Apology of Socrates ends. SapSal 1:15 states programmatically that justice is immortal. ${ }^{14}$ The first part of the book, designed in analogy to the Greek literary genre of logos protreptikos, invites to a life in justice and wisdom (1:1-6:21) and comforts the suffering righteous people by pointing to a life beyond the death line (3:1): But the souls of the righteous are in the hand of God, and no torment will ever touch them. The book has a tripartite structure defined differently by various authors. ${ }^{15}$ We are particularly interested in the first part.

The platonic Socrates thinks that it is not God's will that a better man be injured by a worse and that the slander and envy of the many will harm the righteous. SapSal 2:24 expresses the conviction that through the envy of the devil death entered the world, and those who belong to his party experience it. SapSal works out the idea that God, the Lord of life, does not want death (Knibb 2009):

God did not make death nor does he delight in the destruction of the living. (14) For he created all things that they might exist and the generative forces of the world are wholesome, and there is no destructive poison in them nor is the kingdom of Hades on earth. (n.p.)

Of particular importance is the pointed juxtaposition of the righteous and the impious and the godless who provoke and cause the death of the righteous with words and deeds, counting him friend, making with him a pact, worthy as they belong to him (1:16). Against the despair of the pointless death of the pious and the righteous, SapSal articulates the hope that death does not have the last word, but the ultimate word belongs to the only one true living and life-creating God. This hope is expressed also in Plato's Apology of Socrates (29f. \& 40f.). From the idea of the image of God in the Creation account of Genesis (Gn 1:26-27), SapSal develops the hope of immortality and the afterlife perspective of the righteous to be by God eternally (2:23): God created human beings for incorruption and made them the image of his own nature. Therefore, death is only apparently the end of the righteous. SapSal expresses the hope that the righteous will be in God's hands even after death (3:1): The souls of the righteous are in the hand of God, and no torment will ever touch them. This statement recalls the last words of Socrates and implies the ideas of martyrdom and resurrection of the deaths that unfold in Isaiah 26:14.19, 2Macc 6f., Daniel 12:2-3 and $4 \mathrm{Macc}^{16}$ (cf. Ezekiel 37). Here, it is introduced by the life attitude of the godless (2:1ff.). With regard to human nature, the godless overlooks the fact that God created human beings, and states (Knibb 2009):

14.Translation of Sapientia Salomonis according to Knibb (2009).

15.See Hübner (1999:29f.), Winston (1979:10f.) and Bullard and Hatton (2004:4f.).

16.See Dafni (2015b).
Short and sorrowful is our life, and there is no remedy when a human being dies, and no one is known who returned from Hades. (2) because we came to life by chance and hereafter we shall be as though we have never existed, because the breath in our nostrils is smoke and reason is a spark within the beating of our hearts, when it is extinguished, the body will turn to ashes and the spirit will be dispersed as thin air. (n.p.)

Regarding the reputation in time that Plato addresses in Symposium, ${ }^{17}$ the godless believes that:

[O]ur name will be forgotten in time, and no one will remember our deeds; our life will pass away as the traces of a cloud and will be scattered as mist that is chased by the rays of the sun and weighed down by its heat. (5) For our allotted time is the passing of a shadow, and there is no putting back of our death, because it has been sealed and no one turns it back. (179c)

The cynicism of the godless and wicked people is reflected in the fact that they think they have power over life and death, causing the death of the righteous and the powerless. Also, Socrates thinks that wickedness can run faster than death (39a). SapSal underlines that wickedness blinded the godless (2:[15]). The thoughts of the godless, portrayed as powerful people, who can use their influence to cause suffering and the death of the righteous, are presented in 2:6-20. The use of single words and phraseology seems not to correspond to outspoken comments and to contemporary idiom of the godless but includes the thoughts of the righteous and the opinion of the author of the book as well towards people who practise atheism, even though they know the true God and his will. Having no hope in afterlife, the godless invites who are like him firstly to enjoy the material goods:

Come, therefore, let us enjoy the good things that exist, and let us make good use of the creation as in youth; (7) let us take our fill of costly wine and perfumes, and let no flower of spring pass us by. (8) Let us crown ourselves with rosebuds before they are withered. (9) Let none of us be without share in our revelry; everywhere let us leave signs of enjoyment, because this is our portion and this our lot. (2:6-9)

Secondly, the godless expresses his profound hatred and conspires against the righteous. He urges to look for chances to take advantage of all the righteous and helpless people. The godless tempts and oppresses the righteous and condemns him to die like a criminal:

\footnotetext{
Let us oppress the righteous poor man,

let us not spare the widow

nor have any regard for the hairs, gray with

long years, of the old man. (2:10-20)
}

Verse 11 expresses the will of the godless to enforce the right of the powerful as a universal law (Knibb 2009):

But let our strength be the standard of what righteousness is, for what is weak is proved to be useless. (n.p.)

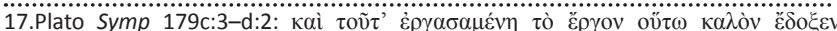

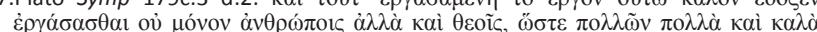

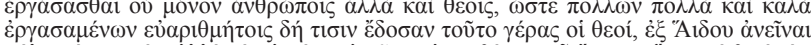

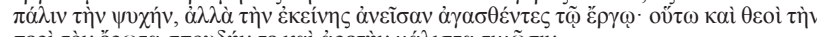

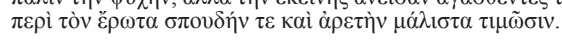


Verse 12 shows that the strength and assertiveness of the godless is based on lies unlike the righteous whose life is based on the education and preservation of the Divine Law. The godless cannot stand to be tested and controlled by the righteous, whose ways of life are according to the Divine Law but against the law of the powerful (Knibb 2009):

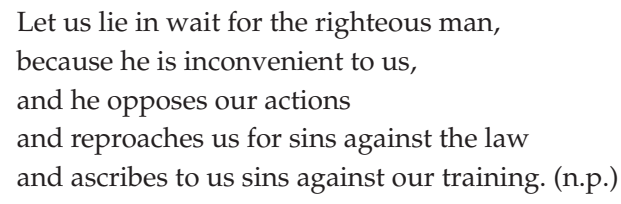

Therefore, the godless afflicts the righteous with the aid of the cruel pretence of testing to see how his peaceful selfcontrol becomes powerless before him and realises that there is no god who could protect him from God's adversaries (see Mt 27:39-44; 15:29-32; Lk 23:35-37. See Mt 4:1-11; Mk 1:12f.; Lk 4:1-13).

Especially, verses 13-18 recall the accusations and the real motives of the slanderers and the prosecutors of Socrates according to the platonic Apology. The godless accuses the righteous that:

13 He professes to have divine knowledge

and calls himself a child of the Lord;

14 he has become a reproof to us to our thoughts.

This verse reverses the order of the Apology and shows that the godless can actually be compared here with the accusers of Socrates:

\section{(15) he is a burden to us even to see.}

The profound hatred against the righteous that tests the godless is explained as follows: the godless cannot stand seeing and hearing him and wants to annihilate him so that he no longer exists. In this way, he wants to silence the voice of conscience forever (Knibb 2009):

\footnotetext{
15 because his life is unlike that of others

and his behavior is different.

16 We are considered by him to be base,

and he keeps distant from our ways as from

uncleanness.

He calls the last end of the righteous happy

and boasts that God is his father. (n.p.)
}

From the charges against Socrates, that he does not believe in god and god's children, arises the question who actually is a child of God and how can the God-man relationship be defined. By speaking of the Righteous as the Son of God and the God as the Father of the Righteous, SapSal takes position on this question and shows that the divine sonship of human beings is not meant in a materialistic or physical way, but in an ethical and mental one.

Unlike Socrates, who tested the others to lead them to the truth, the wisdom and the virtue, the godless pretends to test with the aim to exterminate the righteous physically and ethically:
17 Let us see if his words are true,

and let us test what will happen at the end

of his life;

18 for if the righteous man is a divine son, he will help him and will rescue him from the hand of those who oppose him.

19 Let us afflict him with insult and torture, that we may learn how reasonable he is and may put his forbearance to the test. 20 Let us condemn him to a shameful death, for, according to his words, he will be watched over.

The author of SapSal gives the explanation that the godless denies that the righteous has the knowledge of $\mathrm{God},{ }^{18}$ as he is blinded by his wickedness (21), he does not really know divine mysteries, nor hopes for the wages of holiness, nor recognises the reward for blameless souls (22). The ultimate explanation of moral and ethical corruption as well as physical and eternal death is expressed in SapSal 2:23f.:

23 Because God created human beings for incorruption and made them the image of his own nature,

24 but through the envy of the devil death entered the world, and those who belong to his party experience it.

\section{Conclusions}

From what has been said so far, the problem of atheism is approximated in both texts, the platonic Apology of Socrates and the book of Sapientia Salomonis, from the perspective of the righteous and the godless in the face of God. It is noteworthy that even Socrates speaks of God in singular when it comes to his personal relationship to the supernatural.

SapSal seems to be the Jewish answer to the unjust death of the wise and righteous Socrates, with special reference to the Jewish situation in the Hellenistic-Roman era (cf. 2Macc 6f. and 4Macc). But it is formulated in such a way that its formulations are applicable to all temporal and cultural conditions, as at every time and place, the righteous must suffer under the yoke of the wicked people.

\section{Acknowledgements Competing interests}

The author declares that they have no financial or personal relationships which may have inappropriately influenced them in writing this article.

\section{Author's contributions}

E.G.D. is the sole author of this research article.

\section{Ethical considerations}

This article followed all ethical standards for a research without direct contact with human or animal subjects.

18.See Dafni (2017:232-269). 


\section{Funding information}

This research received no specific grant from any funding agency in the public, commercial, or not-for-profit sectors.

\section{Data availability statement}

Data sharing is not applicable to this article as no new data were created or analysed in this study.

\section{Disclaimer}

The views and opinions expressed in this article are those of the author and do not necessarily reflect the official policy or position of any affiliated agency of the author.

\section{References}

Bullard, R.A. \& Hatton, H.A., 2004, A Handbook on the Wisdom of Solomon, United Bible Societies, New York, N.Y.

Dafni, E.G., 2001,'Natürliche Theologie in Lichte des hebräischen und griechischen Alten Testaments', Theologische Zeitschrift 57(3), 295-310.

Dafni, E.G., 2015a, 'Collective guilt and selfsacrifice in Sophocles' Antigone and II \& IV Maccabees. Preliminary cultural-critical remarks', Journal for Semitics 24(1), 198-215. https://doi.org/10.25159/1013-8471/3444

Dafni, E.G., 2015b, 'Genesis 2-3 and Alcibiades's speech in Plato's symposium: A cultural critical reading', HTS Teologiese Studies/Theological Studies 71(1), Art. \#2903, 6 pages. https://doi.org/10.4102/hts.v71i1.2903

Dafni, E.G., 2017, ,'Gotteserkenntnis in Platon's Theaitetus und in der Septuaginta. Kulturkritische und Sprachtheologische Bemerkungen', in Eadem (ed.),
Gottesschau-Gotteserkenntnis. Studien zur Theologie der Septuaginta 1, WUNT 387, pp. 232-269, Mohr Siebeck Verlag, Tübingen.

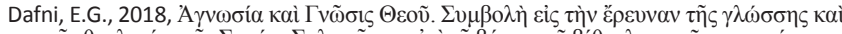

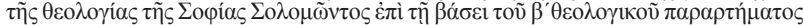

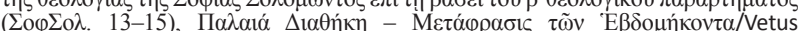
Testamentum - Septuaginta 1, Ostracon-Publishing, Thessaloniki.
Engel, H., 2011, 'Sophia Salomonos/Sapientia Salomonis/Die Weisheit Salomos', in M. Karrer \& W. Kraus (eds.), Septuaginta Deutsch. Erläuterungen und Kommentare zum griechischen Alten Testament, Bd II: Psalmen bis Daniel, 2127ff., Deutsche Bibelgesellschaft, Stuttgart.

Engel, H. \& Hiecke, T., 2005, 'Das Buch der Weisheit', in E. Zenger (ed.), Stuttgarter Altes Testament, pp. 1290-1318, Einheitsübersetzung mit Kommentar und Lexikon, Stuttgart.

Fowler, H.N., 1966, Plato. Plato in twelve volumes, Vol. 1, transl. H.N. Fowler; Introduction by W.R.M. Lamb, Harvard University Press, Cambridge, MA \& William Heinemann Ltd., London, viewed 25 May 2019, from https://www. perseus.tufts.edu/hopper/text?doc=Perseus\%3Atext\%3A1999.01.0170\%3At ext \%3DApol.

Friedländer, P., 1957, Platon, Bd 2: Die platonischen Schriften, erste periode, 2. verbesserte und erweiterte Auflage, pp. 143-158, De Gruyter, Berlin.

Fuhrmann, M. (transl. \& ed.), 1989, Platon, apologie des Sokrates, Griechisch/ Deutsch, Reclam, Stuttgart.

Gauss, H., 1954, Philosophischer Handkommentar zu den Dialogen Platos, vol. 1/2, pp. 23-71, Die Frühdialoge, Herbert Lang \& Cie, Bern.

Hübner, H., 1999, Die Weisheit Salomons - Liber Sapientiae Salomonis, ATD.Apokr. 4, pp. 153-188, Vandenhook \& Ruprecht, Göttingen.

Knibb, M.A., 2009, 'Wisdom of Salomon', in A. Pietersma \& B.G. Wright III (eds.), A New English Translation of the Septuagint, Oxford University Press, Oxford (corrections and emendations of June 2014), viewed 25 May 2019, from https:// ccat.sas.upenn.edu/nets/ edition/.

Natorp, P., 1961, Platos Ideenlehre. Eine Einführung in den Idealismus, pp. 4-10, Wissenschaftliche Buchgesellschaft, Darmstadt (1921), ND.

Ritter, C., 1923, Platon. Sein Leben, seine Schriften, seine Lehre, Bd 2, pp. 368-384, Beck, München.

Van Eemeren, F. \& Grootendorst, R., 1992, Argumentation, communication and fallacies: A pragma-dialectical perspective, 208ff., Lawrence Erlbaum, Hillsday, NJ.

Vögtle, A. \& Nützel, J.M. (eds.), 2000, Neue Jerusalemer Bibel. Einheitsübersetzung mit dem Kommentar der Jerusalemer Bibel, neu bearbeitete und erweiterte Ausgabe Deutsch, Einleitung zum Buch der Weisheit, 918ff., Herder, Freiburg Basel-Wien.

Von Kutschera, F., 2002, Platons Philosophie I, Die frühen Dialoge, pp. 71-85, Mentis, Paderborn.

Von Wilamowitz-Moellendorff, U., 1919, Platon. Bd 2: Beilagen und Textkritik, pp. 47-53, Weidmannsche Buchhandlung, Berlin.

Winston, D., 1979, The wisdom of Solomon. A new translation with introduction and commentary, AnchB 43, Doubleday \& Co, New York, NY. 